JFFI. 2018; 5(2) 299-308

www.jurnal.farmasi.umi.ac.id/index.php/fitofarmakaindonesia

\title{
UJI AKTIVITAS ANTIOKSIDAN EKSTRAK DAUN DARUJU (Acanthus ilicifolius L.) DENGAN METODE PEREDAMAN RADIKAL BEBAS 1,1-DIPHENYIL-2-PICRYLHIDRAZIL (DPPH)
}

\author{
Selpida Handayani*, Ahmad Najib, Nurul Purnama Wati \\ Laboratorium Farmakognosi-Fitokimia, Fakultas Farmasi, Universitas Muslim Indonesia \\ *selpida.handayani@umi.ac.id
}

\begin{abstract}
ABSTRAK
Sea holly leaves (Acanthus ilicifolius L.) belongs to Acanthaceae family, contain flavonoid compounds, alkaloids, an phenols. This research aimed to determine the antioxidant activity of sea holly leaf extract by free radical damping method 1,1-Diphenyl-2-Picrylhydrazil (DPPH). The extraction method multilevel maseration using $n$ hexane extract, ethyl acetate extract, and ethanol extract is 1,55\%, 0,65\% and 4,97\% respectively. On each extract, the antioxidant activity was assayed by DPPH free radical inhibition method by measuring is absorbance at the maximum wavelength of $515 \mathrm{~nm}$ using UV-VIS spectrophometer with quercetin compound as comparator. The result of antioxidant assay showed that $I C_{50}$ value, ethanol extract is $34,659 \mu \mathrm{g} / \mathrm{mL}$ (strong antioxidant), ethyl acetate extract is $162,512 \mu \mathrm{g} / \mathrm{mL}$ (weak antioxidant), $n$-hexane extract is $361,730 \mu \mathrm{g} / \mathrm{mL}$ (not active as antioxidant).
\end{abstract}

Keywords: Antioxidant, Acanthus ilicifolius L, DPPH, Acanthaceae, Sea holly leaves

\section{PENDAHULUAN}

Berubahnya pola hidup masyarakat serta pola makan yang tidak benar dan pertambahan usia mengakibatkan pembentukan radikal bebas dalam tubuh. Padatnya aktivitas kerja cenderung menyebabkan masyarakat mengkonsumsi makanan yang serba instan dan menerapkan pola makan yang tidak sehat. Makanan yang tidak sehat akan menyebabkan akumulasi jangka panjang terhadap radikal bebas di dalam tubuh. Lingkungan tercemar, kesalahan pola makan dan gaya hidup, mampu merangsang tumbuhnya radikal bebas (free radical) yang dapat merusak tubuh (Nugraha, Batubara, \& Ginting, 2015, h. 1).

Untuk melindungi tubuh dari radikal bebas, terdapat senyawa antioksidan sebagai penangkal dan dapat menstabilkan radikal bebas dengan melengkapi kekurangan elektron radikal bebas sehingga dapat menghambat terjadinya reaksi berantai (Julfitriyani, Runtuwene, Wewengkang, 2016, h.95).

Antioksidan adalah senyawa yang dapat melindungi sel dari kerusakan yang disebabkan radikal bebas. Antioksidan akan berinteraksi dengan cara menstabilkan radikal bebas sehingga dapat mencegah kerusakan karena radikal bebas yang mungkin dapat terjadi (Hamid et al., 2010, h.142). Antioksidan alami berupa senyawa flavonoid yang merupakan kelompok senyawa polifenol yang berasal dari tanaman seperti teh, buah -buahan dan sayuran. Senyawa flavonoid dapat bekerja langsung untuk meredam radikal bebas oksigen seperti superoksida yang dihasilkan dari reaksi enzim xantin oksidase. Selain bekerja sebagai antioksidan, flavonoid dapat bekerja sebagai bekerja sebagai antiaterosklerosis, antitrombogenik, antiinflamasi, antitumor, antivirus dan antiosteoporosis (Simanjuntak, 2012).

Dey Avijit et al (2012, h.153) telah meneliti tentang aktivitas ekstrak metanol pada tanaman daruju (Acanthus ilicifolius L.) dengan menggunakan 1,1 Diphenil 2 Picrylhidrazil (DPPH) hasilnya menunjukkan bahwa nilai $\mathrm{IC}_{50}$ ekstrak metanol tanaman daruju (Acanthus ilicifolius L) yaitu 5.1 $\mu \mathrm{g} / \mathrm{ml}$ yang termasuk pada kategori intensitas antioksidan yang sangat kuat.

Daun daruju (Acanthus ilicifolius L.) mengandung Protein, Alkaloid, Resin, Steroid, Tanin, Glikosida, karbohidrat, Saponin, Steroid, Sterol, Terpenoid, Fenol, dan katakol (Sachin, Shahana \& Gaikwad Rupali, 2014 h. 27). Daruju mengandung flavonoid, triterpenoid, derivate asam lemak, dan saponin. Daun daruju (Acanthus ilicifolius L.) memili kandungan flavonoid yaitu Quercetin, quercetin 3-O- $\beta$-D-glucopyranoside dan vitexin (Saranya et al., 2015, h.245).

Daruju (Acanthus ilicifolius L) digunakan sebagai anti inflamasi, diabetes, asma, hepatitis, dan pengobatan rheumatoid (Firdaus, Prihanto, \& Nurdiani, 2013, h. 18). Sedangkan pada daun daruju (Acanthus ilicifolius $\mathrm{L}$ ) digunakan untuk mengobati 
rematik dan luka pada panah beracun, asma, pengobatan akibat gigitan ular dan rematik (Wostmann \& Liebezeit, 2008). Dalam pengobatan tradisional Cina (TCM) daruju (Acanthus ilicifolius L.) digunakan untuk mengobati peradangan, hepatitis, bengkak Limpa, asma dan tumor ganas (Lin Liu et al., 2013, h. 796).

Berdasarkan uraian di atas, maka telah dilakukan penelitian sebagai skrining awal untuk menguji toksisitas ekstrak daun daruju (Acanthus ilicifolius L.) dengan menggunakan metode peredaman radikal bebas 1,1-diphenyl-2picrylhidrazil (DPPH).

\section{METODE PENELITIAN}

\section{A. Pengambilan dan Pengolahan Sampel}

Daun daruju (Acanthus ilicifolius L.) yang telah dikumpulkan, dicuci bersih terlebih dahulu, setelah itu dilakukan perajangan. Selanjutnya, dikeringkan dengan cara diangin-anginkan tanpa paparan sinar matahari langsung, kemudian diserbukkan dan siap untuk diekstraksi (Munawar, 2016).

\section{B. Ekstraksi Sampel}

Simplisia daun daruju (Acanthus ilicifolius L.) ditimbang sebanyak 200 gram dan dimasukkan kedalam wadah maserasi, kemudian ditambahkan pelarut dengan perbandingan 1:10. Prosedur ekstraksi dilakukan dengan merendam sampel dengan nHeksan, etil asetat dan etanol secara berurutan. Dimaserasi selama 3 x 24 jam, dimana hasil maserasi kemudian disaring dengan kertas saring sehingga dihasilkan ekstrak cair dan residu. Proses maserasi dilakukan 2 kali, kemudian ekstrak cair yang diperoleh kemudian dipekatkan dengan alat Rotary Vacum Evaporator pada suhu $50^{\circ} \mathrm{C}$ hingga diperoleh ekstrak kental n-Heksan, etil asetat dan etanol (Putranti, 2013, h.14).

\section{Uji Skrining \\ 1. Flavonoid}

Ekstrak dilarutkan kemudian dipipet $1 \mathrm{~mL}$ dan ditambahkan serbuk Mg secukupnya lalu ditetesi dengan larutan asam klorida pekat sebanyak 10 tetes. Positif mengandung flavonoid jika terjadi perubahan warna maka positif mengandung flavonoid (Gafur, Isa, dan Bialangi, 2014, h.4).

\section{Alkaloid}

Ekstrak dimasukkan kedalam masingmasing tabung reaksi kemudian ditetesi (Syarif et al., 2015, h.84):

a. $\mathrm{HCl} \mathrm{0,5} \mathrm{N}$ dan pereaksi Mayer, jika mengandung alkaloid maka akan menghasilkan endapan kuning. b. $\mathrm{HCl} 0,5 \mathrm{~N}$ dan pereaksi Bauchardat, jika mengandung alkaloid maka akan menghasilkan endapan coklat.

c. $\mathrm{HCl} 0,5 \mathrm{~N}$ dan pereaksi Dragendrof, jika mengandung alkaloid akan menghasilkan endapan jingga.

3. Saponin

Uji busa: Larutan uji dicampur dengan air dan dikocok. Diamati pembentukan buih, buih stabil selama 15 menit maka menandakan adanya saponin (Waris, Najib, \& Pratiwi, 2016, h.344).

\section{Fenol}

Uji $\mathrm{FeCl}_{3}$ : Ekstrak ditambahkan 3-4 tetes larutan $\mathrm{FeCl}_{3}$. Pembentukan warna hijau atau hijau biru menunjukkan adanya fenol (Syarif et al., 2015, h.84).

\section{Steroid}

Ekstrak dilarutkan kemudian dipipet sebanyak $1 \mathrm{~mL}$ dan ditambahkan $2 \mathrm{~mL}$ kloroform lalu dikocok, kemudian ditambahkan 2 tetes larutan Lieberman - Bauchard. Terbentuknya larutan berwarna merah untuk pertama kali kemudian berubah menjadi biru dan hijau menunjukkan reaksi positif (Syarif et al 2015, h.84).

\section{Pengujian Antioksidan \\ 1. Pengujian Kualitatif}

Ekstrak n-Heksan, etil asetat dan etanol dilarutkan dengan menggunakan pelarut yang sesuai kemudian ditotolkan pada lempeng silika gel $\mathrm{F}_{254}$ lalu dielusi dengan menggunakan eluen n-heksan : etil asetat dengan perbandingan 4:6 pada ekstrak nheksana, eluen n-Heksan : etil asetat dengan perbandingan 6:4 pada ekstrak etil asetat dan eluen nHeksan : etil asetat dengan perbandingan 3:7 pada ekstrak etanol . Lempeng tersebut disemprot dengan menggunakan asam sulfat $10 \%$ dan kemudian lempeng disemprotkan dengan 1,1-diphenyl-2picrylhydrazyl (DPPH) dan dibiarkan mengering hingga terjadi perubahan dengan terbentuknya noda berwarna kuning dengan latar berwarna ungu pada lempeng KLT (Syarif et al., 2015, h.85).

Penentuan panjang gelombang maksimum terhadap larutan DPPH dilakukan dengan cara mengukur pada panjang gelombang $515 \mathrm{~nm}$, kemudian dari hasil pengukuran ditentukan panjang gelombang maksimumnya (Syarif et al., 2015, h.85).

2. Pengujian Kuantitatif

a. Pembuatan Larutan DPPH

Sebanyak 3,5 mg DPPH dilarutkan dengan metanol dalam labu ukur sampai $100 \mathrm{~mL}$ sehingga diperoleh larutan dengan konsentrasi 35 ppm. 


\section{b. Pembuatan Larutan Sampel}

Sebanyak $10 \mathrm{mg}$ sampel masing-masing dilarutkan dengan $10 \mathrm{~mL}$ metanol p.a dalam labu ukur $10 \mathrm{~mL}$ sehingga diperoleh konsentrasi 1000 ppm. Kemudian dilakukan pengenceran dalam labu ukur $10 \mathrm{~mL}$ dengan menambahkanmetanol p.a sehingga diperoleh larutan dengan konsentrasi 20, 40, 60, 80 dan 100 ppm.

\section{c. Pembuatan Larutan Kuersetin sebagai Pembanding \\ Sebanyak $5 \mathrm{mg}$ larutan perbandingan} dilarutkan dengan $50 \mathrm{~mL}$ methanol p.a dalam labu ukur 50mL sehingga diperoleh konsentrasi 100 ppm. Kemudian dilakukan pengenceran dalam ukur $50 \mathrm{~mL}$ dengan menambahkan methanol p.a sehingga diperoleh larutan dengan konsentrasi 2, 4, 6, 8 dan 10 ppm.

\section{d. Penentuan Panjang Gelombang Maksimal}

Sebanyak 3,5 mL larutan DPPH $35 \mathrm{ppm}$ dan ditambahkan dengan $1 \mathrm{~mL}$ metanol. Serapan larutan diukur dengan spektrofotometer UV-Vis pada panjang gelombang $515 \mathrm{~nm}$.

\section{e. Penentuan Aktivitas Antioksidan}

Penentuan aktivitas antioksidan dilakukan dengan cara $4 \mathrm{~mL}$ larutan DPPH 1000 ppm ditambah dengan masing-masing $1 \mathrm{~mL}$ larutan uji konsentrasi 20, 40, 60, 80 dan 100 ppm. Larutan ini kemudian diukur absorbansinya pada panjang gelombang maksimum. Sebagai pembanding digunakan kuersetin dengan konsentrasi 2, 4, 6, 8 dan 10 ppm dengan perlakuan yang sama dengan larutan uji.

\section{f. Penentuan Persentase Peredaman}

$\mathrm{A} 1=$ absorbansi kontrol

$$
\% \text { inhibisi }=\frac{\mathrm{A} 1-\mathrm{A} 2}{\mathrm{~A} 1} \times 100 \%
$$

A2 = absorbansi sampel

Nilai $\mathrm{IC}_{50}$ merupakan bilangan yang menunjukkan konsentrasi sampel uji yang memberikan peredaman sebesar 50\% (mampu menghambat atau meredam proses oksidasi sebesar $50 \%$ ). Nilai $\mathrm{IC}_{50}$ ditentukan dengan cara dibuat kurva linear antara konsentrasi larutan uji (sumbu $\mathrm{x}$ ) dan $\%$ peredaman (sumbu y) dari persamaan $\mathrm{y}=\mathrm{a}+\mathrm{bx}$ dapat di hitung nilai $\mathrm{IC}_{50}$ dengan menggunakan rumus

$$
\mathrm{IC}_{50}=\frac{(50-a)}{b}
$$

diuji dikatakan mempunyai efek toksik apabila harga $\mathrm{LC}_{50}<$ dari $1000 \mathrm{mg} / \mathrm{mL}$.

\section{HASIL DAN PEMBAHASAN}

Radikal bebas adalah atom atau molekul yang tidak stabil dan sangat reaktif karena mengandung satu atau lebih elektron tidak berpasangan pada orbital terluarnya. Untuk mencapai kestabilan atom atau molekul, radikal bebas akan bereaksi dengan molekul disekitarnya untuk memperoleh pasangan elektron. Reaksi ini akan berlangsung terus-menerus dalam tubuh dan bila tidak dihentikan akan menimbulkan berbagai penyakit seperti kanker, jantung, katarak, penuaan dini, serta penyakit degeneratif lainnya. Oleh karena itu tubuh memerlukan suatu substansi penting yaitu antioksidan yang mampu menangkap radikal bebas tersebut sehingga tidak dapat menginduksi suatu penyakit (Kikuzaki et al., 2002).

Senyawa antioksidan yaitu senyawa yang mampu menetralisir atau menstabilkan radikal bebas dengan cara melengkapi kekurangan elektron pada radikal bebas tersebut. Substansi ini mampu mencegah terjadinya reaksi berantai dari pembentukan radikal bebas yang dapat menimbulkan stress oksidatif (ketidakseimbangan antara prooksidan dan antioksidan). Ada banyak bahan pangan yang dapat menjadi sumber antioksidan alami, misalnya rempah-rempah, teh, coklat, dedaunan, biji-biji, serelia, sayur-sayuran, enzim dan protein (Cheleng, 2015, h.2).

Pada penelitian ini telah dilakukan uji aktivitas antioksdain ekstrak daun daruju (Acanthus illicifolius L.) serta menentukan nilai ic ${ }_{50}$ dari daun daruju dengan menggunakan variasi pelarut untuk menentukan pelarut mana yang mengandung nilai $\mathrm{IC}_{50}$ yang baik serta mendekati range. Adapun tujuan penelitian ini adalah untuk mengetahui aktivitas antioksidan ekstrak daun daruju (Acanthus ilicifolius L.).

Pada penelitian ini menggunakan daun daruju (Acanthus ilicifolius L.) yang berasal dari Makassar. Daun daruju segar kemudian di dideterminasi di laboratorium farmakognosifitokimia untuk memastikan bahwa tanaman yang digunakan merupakan salah satu tanaman penting dalam proses selanjutnya. Hasil identifikasi tanaman menunjukkan bahwa sampel adalah Acanthus ilicifolius L. dari suku Acanthaceae.

Selanjutnya Sampel daun daruju (Acanthus ilicifolius L.) yang segar dibersihkan dan dikeringkan, kemudian diserbukkan sehingga siap untuk diekstraksi. Sampel ditimbang sebanyak 200 gram, kemudian diekstraksi dengan menggunakan ekstraksi bertingkat yang bertujuan untuk mendapatkan senyawa aktif dengan tingkat kepolaran yang berbeda dengan menggunakan tiga pelarut yaitu n-heksana, etil asetat, dan etanol. Kemudian masingmasing ekstrak cair diuapkan menggunakan alat 
rotary vacum evaporator untuk menghasilkan ekstrak kental.
Adapun hasil yang diperoleh dari ekstraksi daun daruju (Acanthus ilicifolius L.) dapat dilihat pada tabel dibawah ini:

Tabel 1. Berat Ekstrak dan Persen Rendemen

\begin{tabular}{cccc}
\hline $\begin{array}{c}\text { Jenis } \\
\text { pelarut }\end{array}$ & $\begin{array}{c}\text { Berat sampel kering } \\
(\mathbf{g})\end{array}$ & $\begin{array}{c}\text { Berat } \\
\text { Ekstrak } \\
(\mathbf{g})\end{array}$ & $\begin{array}{c}\text { Persen } \\
\text { Rendemen (\%) }\end{array}$ \\
\hline$n$-Heksan & 200 & 3,10 & 1,55 \\
Etil & 200 & 1,29 & 0,65 \\
Asetat & 200 & 4,98 & 4,97 \\
Etanol & & & \\
\hline
\end{tabular}

Setelah didapat ekstrak kental dari daun daruju (Acanthus ilicifolius L.) kemudian dilakukan skrinning fitokimia untuk mengetahui kandungan kimia dari ekstrak $n$-heksana, etil asetat, dan etanol. Uji skrinning fitokimia yang dilakukan adalah alkaloid, fenol, flavonoid, saponin dan steroid. Adapun hasil skrinning fitokimia dari ekstrak daun daruju (Acanthus ilicifolius L.) dapat diliihat dibawah ini:

Tabel 2. Data Hasil Skrining Fitokimia Ekstrak

\begin{tabular}{|c|c|c|c|c|}
\hline \multirow{2}{*}{ Uji } & \multicolumn{3}{|c|}{ Ekstrak Kental } & \multirow{2}{*}{ Pustaka } \\
\hline & n-Heksan & Etil asetat & Metanol & \\
\hline 1. Flavonoid & - & + & + & $\begin{array}{l}\text { Positif jika terjadi perubahan warna (Endang } \\
\text { 2014) }\end{array}$ \\
\hline \multicolumn{5}{|l|}{ 2. Alkaloid } \\
\hline a. Bouchardat & + & + & + & $\begin{array}{l}\text { Positif jika terbentuk endapan coklat (Syarif } \\
\text { et al 2015) }\end{array}$ \\
\hline b. Mayer & + & + & + & $\begin{array}{l}\text { Positif jika terbentuk endapan kuning } \\
\text { (Syarif } \text { et al 2015) }\end{array}$ \\
\hline c. Dragendorf & + & + & + & $\begin{array}{l}\text { Positif jika terbentuk endapan jingga (Syarif } \\
\text { et al 2015) }\end{array}$ \\
\hline 3. Saponin & - & - & - & $\begin{array}{l}\text { Positif jika terbentuk busa (Waris, Najib, \& } \\
\text { Pratiwi 2016) }\end{array}$ \\
\hline 4. Fenol & - & + & + & $\begin{array}{l}\text { Positf jika terbentuk warna hijau/ hijau biru } \\
\text { (Syarif et al 2015) }\end{array}$ \\
\hline 5. Steroid & - & + & - & $\begin{array}{l}\text { Positif jika berwarna merah berubah } \\
\text { menjadi biru/hijau (Syarif et al 2015) }\end{array}$ \\
\hline
\end{tabular}

Keterangan: $\quad(+)=$ Positif mengandung senyawa uji

$(-)$ = Negatif mengandung senyawa uji
Dari tabel diatas diketahui ektrak n-heksana mengandung alkaloid, ekstrak etil asetat mengandung flavonoid, alkaloid, fenol dan steroid, dan pada ekstrak etanol mengandung flavonoid, alkaloid, fenol serta steroid. Kandungan fenol yang di dapat pada ekstrak etil asetat dan etanol tetapi tidak didapatkan pada ekstrak n-heksana menunjukkan bahwa senyawa fenol cenderung larut pada pelarut polar. Menurut Chundakkadu (2011) daun daruju (Acanthus ilicifolius L.) pada ekstrak methanol memiliki kandungan kimia saponin, alkaloid, terpenoid, flavonoid, antrakuinon dan tannin.

Selanjutnya dilakukan uji kualitatif dan uji kuantitatif dengan menggunakan metode peredaman bebas DPPH. Alasan penggunaan DPPH untuk metode penangkapan radikal mempunyai keuntungan yaitu: mudah digunakan, mempunyai tingkat sensitivitas tinggi, dan dapat menganalisis sejumlah 
besar sampel dalam jangka waktu yang singkat selain itu secara teknis simpel, dapat dikerjakan dengan cepat dan hanya membutuhkan spektrofotometer UV-Vis.

Pada pengujian antioksidan diawali dengan uji kualitatif dimana menggunakan kromatografi lapis tipis. Uji kualitatif dilakukan untuk mengetahui ada tidaknya aktivitas antioksidan pada ekstrak daun daruju. Uji kualitatif diawali dengan melarutkan Ekstrak daun daruju dengan masing-masing pelarut, setelah itu ditotolkan pada lempeng klt. Kemudian dielusi dengan n-heksana dan etil asetat menggunakan perbandingan pada masing-masing ekstrak yaitu pada ekstrak n-heksana menggunakan eluen n-heksana : etil asetat (4:6), ekstrak etil asetat menggunakan eluen $n$-heksana : etil asetat ( $6: 4$ ) dan ekstrak etanol menggunakan eluen n-heksana : etil asetat ( 3:7 ). Kemudian diamati pada sinar uv 254 dan $366 \mathrm{~nm}$. Lempeng disemprot dengan asam sulfat $10 \%$ dan selanjutnya disemprot dengan DPPH, didiamkan selama 30 menit dan diamati perubahan warna dari ungu menjadi kuning. Senyawa antioksidan akan bereaksi dengan radikal DPPH melalui mekanisme donasi atom hidrogen dan menyebabkan terjadinya peluruhan warna dari ungu ke kuning (Handayani, Ahmad dan Sudir 2014, h.90). Adapun hasil dari uji kualitatif ekstrak daun daruju dapat dilihat pada gambar:

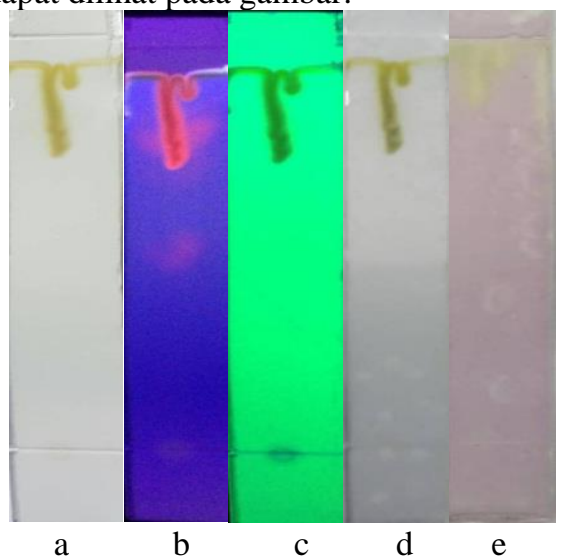

Gambar 1. Kromatografi lapis tipis pemantauan ekstrak n-heksana dengan fase silica gel F254, fase gerak n-heksana-etil asetat (4:6), (a) sinar tampak, (b) UV 366, (c) UV 254, (d) $\mathrm{H}_{2} \mathrm{SO}_{4} 10 \%$ dibawah sinar tampak, (e) DPPH

Berdasarkan gambar 1 hasil uji kualitatif ekstrak n-heksana daun daruju (Acanthus ilicifolius L.) yaitu ekstrak n-heksana daun daruju ditotolkan pada lempeng KLT dan dielusi dengan eluen nheksan : etil asetat dengan perbandingan 4:6, diamati pada sinar uv 254 dan uv 366 kemudian disemprot dengan menggunakan larutan asam sulfat dan larutan DPPH. Hasil yang diperoleh dari uji kualitatif ekstrak n-heksana daun daruju menunjukkan hasil positif mengandung antioksidan yang ditandai dengan terbentuknya warna kuning dengan latar ungu menunjukkan adanya aktivitas antiradikal bebas.

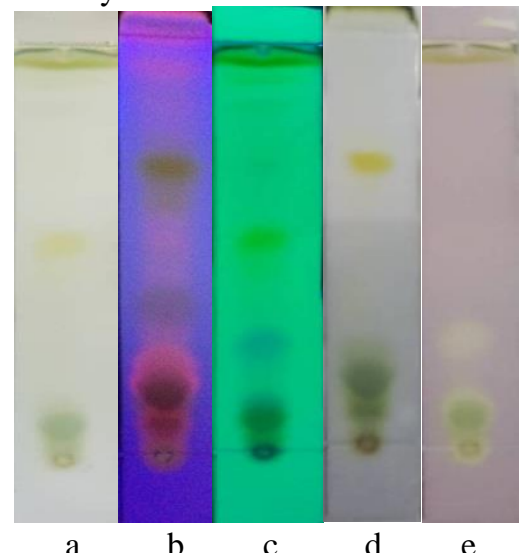

Gambar 2. Kromatografi lapis tipis pemantauan ekstrak etil asetat dengan fase silica gel F254, fase gerak n-heksana-etil asetat (6:4), (a) sinar tampak, (b) UV 366, (c) UV 254, (d) $\mathrm{H}_{2} \mathrm{SO}_{4} 10 \%$ dibawah sinar tampak, (e) DPPH

Berdasarkan gambar 2 hasil uji kualitatif ekstrak n-heksana daun daruju (Acanthus ilicifolius L.) yaitu ekstrak etil asetat daun daruju ditotolkan pada lempeng KLT dan dielusi dengan eluen nheksan : etil asetat dengan perbandingan 6:4, diamati pada sinar uv 254 dan uv 366 kemudian disemprot dengan menggunakan larutan asam sulfat dan larutan DPPH. Hasil yang diperoleh dari uji kualitatif ekstrak etil asetat daun daruju menunjukkan hasil positif mengandung antioksidan yang ditandai dengan terbentuknya warna kuning dengan latar ungu menunjukkan adanya aktivitas antiradikal bebas.

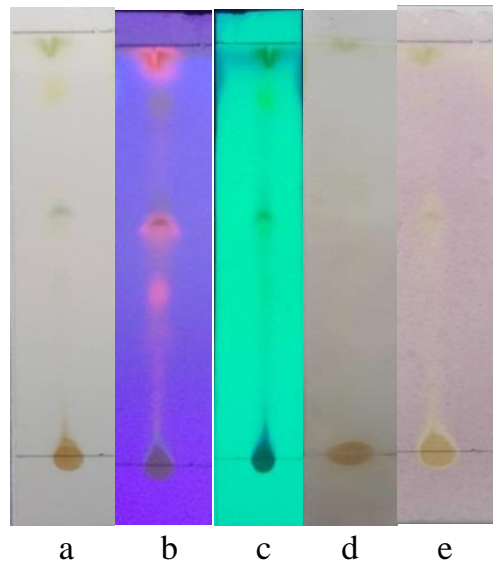

Gambar 3. Kromatografi lapis tipis pemantauan ekstrak etanol dengan fase silica gel F254, fase gerak n-heksana-etil asetat (3:7), (a) sinar tampak, (b) UV 366, (c) UV 254, (d) $\mathrm{H}_{2} \mathrm{SO}_{4} 10 \%$ dibawah sinar tampak, (e) DPPH 
Berdasarkan gambar 3 hasil uji kualitatif ekstrak n-heksana daun daruju (Acanthus ilicifolius L.) yaitu ekstrak etanol daun daruju ditotolkan pada lempeng KLT dan dielusi dengan eluen n-heksan : etil asetat dengan perbandingan 3:7, diamati pada sinar uv 254 dan uv 366 kemudian disemprot dengan menggunakan larutan asam sulfat dan larutan DPPH. Hasil yang diperoleh dari uji kualitatif ekstrak etanol daun daruju menunjukkan hasil positif mengandung antioksidan yang ditandai dengan terbentuknya warna kuning dengan latar ungu menunjukkan adanya aktivitas antiradikal bebas.

Kemudian dilakukan uji kuantitatif mengetahui berapa kadar nilai $\mathrm{IC}_{50}$ dari ekstrak daun daruju. Pada masing masing ekstrak daun daruju dibuat larutan stok 1000 ppm dan dilarutkan menggunakan metanol pa dikarenakan metanol tidak mempengaruhi dalam reaksi antara sampel uji sebagai antioksidan dengan DPPH sebagai radikal bebas (Syarif et al 2015, h.87). Dari larutan stok tersebut dibuat beberapa konsentrasi 20 ppm, 40 ppm, 60 ppm, 80 ppm dan 100 ppm. Sedangkan untuk konsentrasi pembanding adalah 2 ppm, 4 ppm, 6 ppm, 8 ppm dan 10 ppm. Pembanding yang digunakan sebagai kontrol positif adalah kuersetin. Kuersetin digunakan sebagai pembanding karena merupakan golongan flavonoid yang sering ditemukan dalam tumbuhan dan diketahui memiliki banyak aktivitas biologis, khususnya antioksidan (Perwiratami, Suvery dan Cahyono 2014, h.37).

Kemudian pada masing-masing konsentrasi dipipet 0,5 ml sampel dan ditambahkan 3,5 ml larutan DPPH 35 ppm. Dan pengukuran absorbansi sampel diukur pada panjang gelombang maksimum dengan panjang gelombang $515 \mathrm{~nm}$. Pengukuran aktivitas antioksidan sampel dilakukan pada panjang gelombang $515 \mathrm{~nm}$ yang merupakan panjang gelombang maksimum DPPH (Permana, 2003)

Setelah dilakukan pengerjaan dan pengukuran, dilakukan perhitungan persen inhibisi dan IC50 antiradikal bebas dari ekstrak daun daruju. Persen inhibisi adalah kemampuan suatu bahan untuk menghambat aktivitas radikal bebas yang berhubungan dengan konsentarasi suatu sampel, sedangkan IC50 merupakan salah satu parameter yang digunakan untuk menginterprestasikan hasil dari pengujian DPPH, semakin rendah nilai IC50 dari suatu sampel maka kemampuan sebagai antioksidan semakin besar (Aminah, Muzakir Baits dan Ummi Kalsum 2016, h. 149).

Pada Tabel 3. dapat dilihat hasil pengukuran absorbansi, persentase pengikatan DPPH, dan nilai $\mathrm{IC}_{50}$ dari ekstrak n-Heksan, etil asetat dan etanol daun daruju dan pembanding kuersetin.

Tabel 3. Pengukuran Absorbansi, Persentase inhibisi dari ekstrak n-Heksan, etilasetat dan etanol daun daruju (Acanthus ilicifolius L.)

\begin{tabular}{ccccc}
\hline Sampel & $\begin{array}{c}\text { Konsentrasi } \\
(\mathbf{p p m})\end{array}$ & $\begin{array}{c}\text { Absorbansi } \\
\text { blanko }\end{array}$ & $\begin{array}{c}\text { Absorbansi } \\
\text { sampel }\end{array}$ & \% inhibisi \\
\hline Ekstrak n-Heksan & 20 & 0,763 & 0,659 & 13,630 \\
& 40 & 0,763 & 0,648 & 15,072 \\
& 60 & 0,763 & 0,63 & 17,431 \\
& 80 & 0,763 & 0,614 & 19,528 \\
Ekstrak etil asetat & 100 & 0,763 & 0,594 & 22,149 \\
& 20 & 0,763 & 0,571 & 25,163 \\
& 40 & 0,763 & 0,545 & 28,571 \\
& 60 & 0,763 & 0,524 & 31,323 \\
Ekstrak etanol & 80 & 0,763 & 0,5496 & 34,993 \\
& 100 & 0,763 & 0,461 & 39,580 \\
& 20 & 0,763 & 0,399 & 47,706 \\
& 40 & 0,763 & 0,375 & 50,851 \\
Kuersetin & 60 & 0,763 & 0,353 & 53,735 \\
& 80 & 0,763 & 0,333 & 56,356 \\
& 100 & 0,763 & 0,317 & 58,453 \\
& 2 & 0,763 & 0,631 & 17,300 \\
& 4 & 0,763 & 0,573 & 24,901 \\
& 6 & 0,763 & 0,519 & 31,979 \\
& 8 & 0,763 & 0,483 & 36,697 \\
& 10 & 0,763 & 0,431 & 43,512 \\
\hline
\end{tabular}


Kemudian dibuat persamaan regresi linear antara konsentrasi (ug/mL) sebagai absisnya (sumbu x) dan nilai aktivitas antioksidan (\%) sebagai ordinatnya (sumbu y) dari persamaan regresi tersebut dapat ditentukan nilai $\mathrm{IC}_{50}$ masing-masing ekstrak. Regresi linear yang didapat oleh ekstrak n-Heksan daun daruju adalah $\mathrm{y}=0,1075+11,114$ dengan nilai $\mathrm{R}^{2}$ adalah 0,9917; ekstrak etil asetat daun daruju adalah $\mathrm{y}=0,1763 \mathrm{x}+21,349$ dengan nilai $\mathrm{R}^{2}$ adalah 0,9916 dan ekstrak etanol daun daruju adalah $\mathrm{y}=$
$0,135 \mathrm{x}+45,321$ dengan nilai $\mathrm{R}^{2}$ adalah 0,9945 sedangkan kuersetin adalah $\mathrm{y}=3,211 \mathrm{x}+11,612$ dengan nilai $\mathrm{R}^{2}$ adalah 0,9943 . Kemudian dari regresi linear tersebut dimasukkan dalam persamaan $\mathrm{y}=\mathrm{bx}+$ a, dimana y adalah $\%$ inhibisi 50 dan $\mathrm{x}$ adalah nilai $\mathrm{IC}_{50}$. Grafik hubungan antara konsentrasi ekstrak nHeksan, ekstrak etil asetat, ekstrak etanol daun daruju dan pembanding kuersetin dengan $\%$ inhibisi dapat dilihat pada gambar berikut.

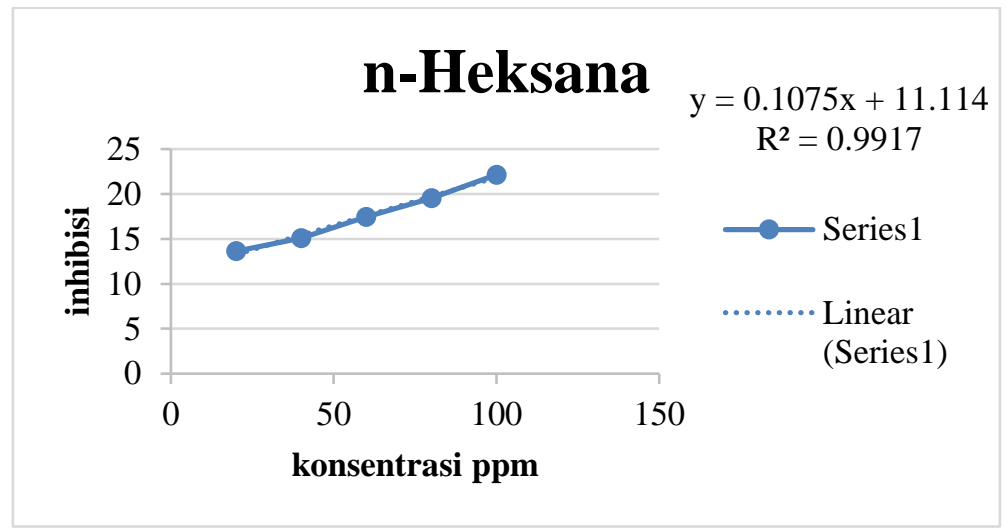

Gambar 4. Grafik hubungan konsentrasi ekstrak n-heksana daun daruju (Acanthus ilicifolius L.) dengan \% inhibisi

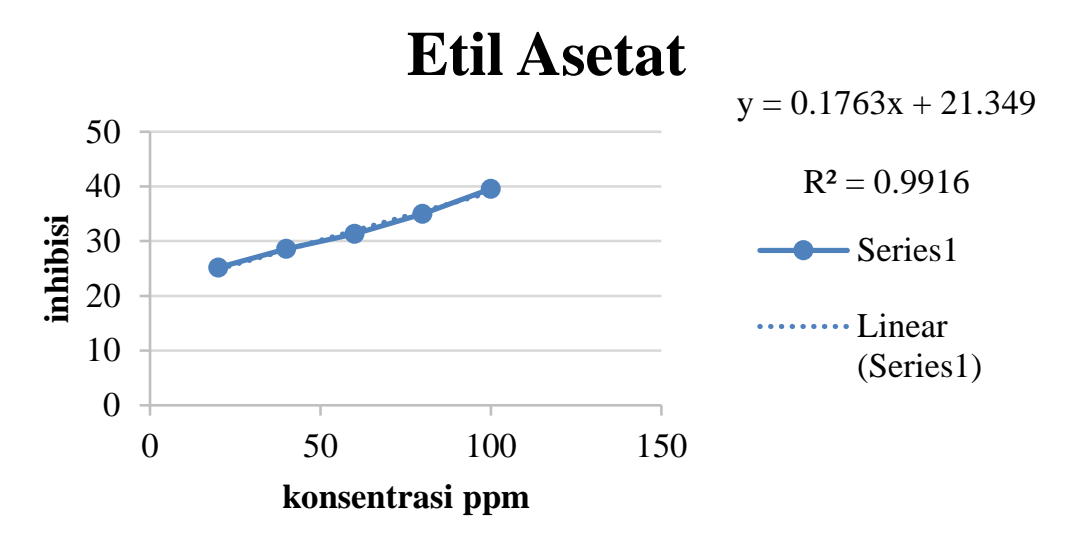

Gambar 5. Grafik hubungan konsentrasi ekstrak etil asetat daun daruju (Acanthus ilicifolius L.) dengan \% inhibisi 


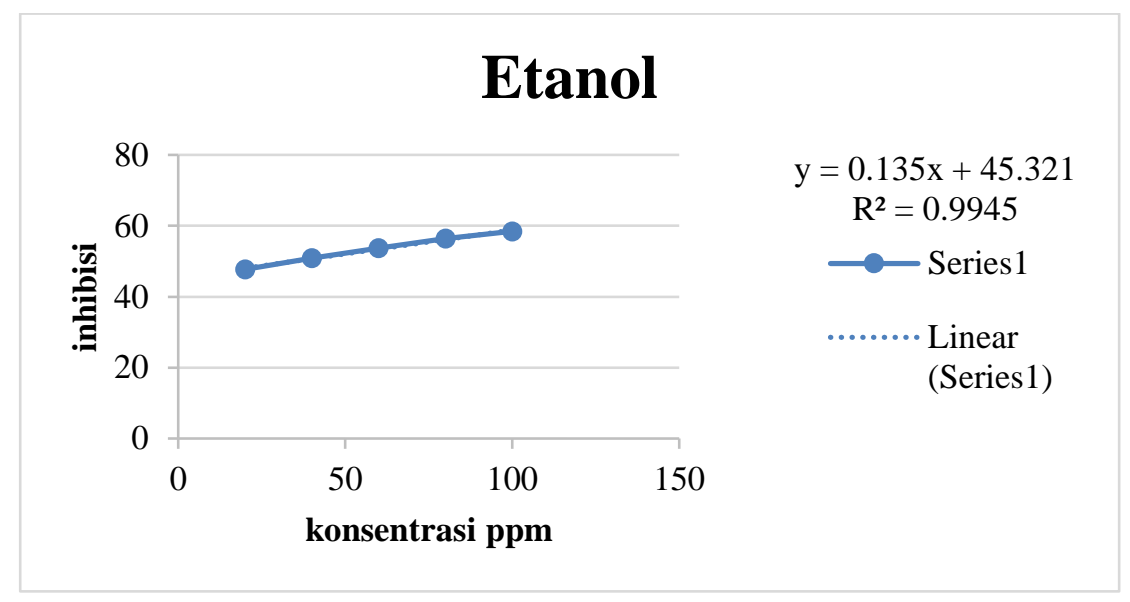

Gambar 6. Grafik hubungan konsentrasi ekstrak etanol daun daruju (Acanthus ilicifolius L.) dengan \% inhibisi

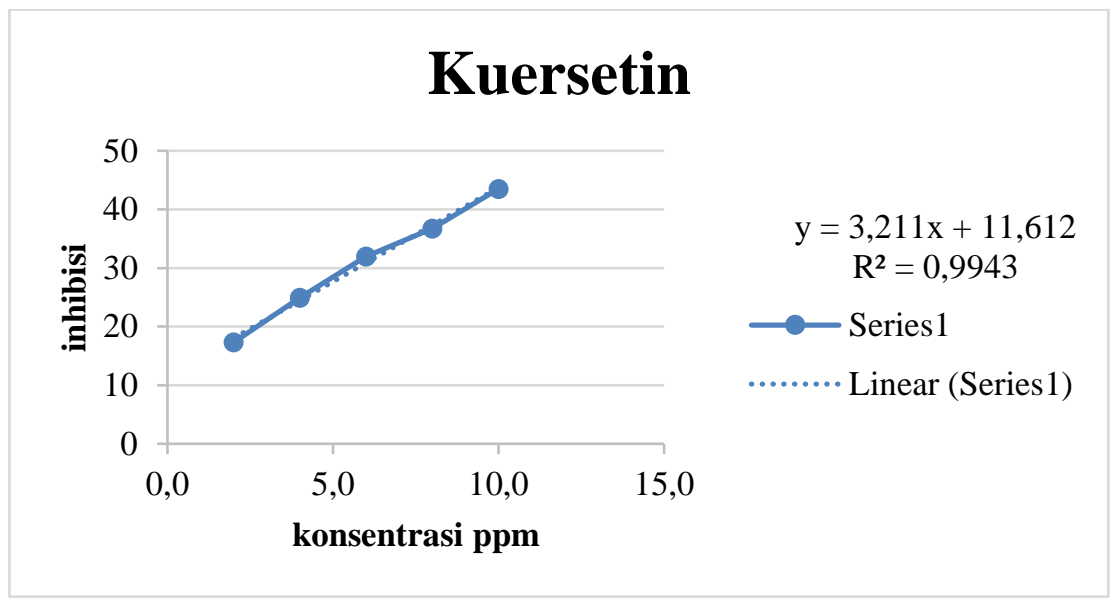

Gambar 7. Grafik hubungan konsentrasi ekstrak kuersetin daun daruju (Acanthus ilicifolius L.) dengan \% inhibisi

Tabel 4. Nilai $\mathrm{IC}_{50}$ dari ekstrak n-Heksan, etil asetat dan etanol daun daruju (Acanthus ilicifolius) dan pembanding kuersetin.

\begin{tabular}{cc}
\hline Sampel & IC $_{\mathbf{5 0}}(\boldsymbol{\mu g} / \mathbf{m L})$ \\
\hline Ekstrak n-Heksan & 361,730 \\
Ekstrak etil asetat & 162,512 \\
Ekstrak etanol & 34,659 \\
Ekstrak Kuersetin & 11,955 \\
\hline
\end{tabular}

Menurut Phongpaichit et al (2007, hal. 522), suatu senyawa dikatakan memiliki aktivitas sebagai antioksidan sangat kuat apabila nilai $\mathrm{IC}_{50}<10 \mu \mathrm{g} / \mathrm{mL}$, kuat apabila nilai $\mathrm{IC}_{50}$ antara $10-50 \mu \mathrm{g} / \mathrm{mL}$, sedang apabila nilai $\mathrm{IC}_{50}$ berkisar antara $50-100 \mu \mathrm{g} / \mathrm{mL}$, lemah apabila nilaiIC ${ }_{50}$ berkisar antara 100-250 $\mu \mathrm{g} / \mathrm{mL}$ dan tidak aktif apabila $\mathrm{IC}_{50}$ diatas $250 \mu \mathrm{g} / \mathrm{mL}$. Dari hasil yang di dapat pada tabel 5 diketahui pada ekstrak n-heksana daun daruju memiliki aktivitas antioksidan yang tidak aktif dengan nilai $\mathrm{IC}_{50}$ adalah $361,730 \mu \mathrm{g} / \mathrm{mL}$, pada ekstrak etil asetat memiliki aktvitas antioksidan lemah dengan nilai $\mathrm{IC}_{50}$ adalah $162,512 \mu \mathrm{g} / \mathrm{mL}$ dan pada ekstrak etanol daun daruju memiliki aktivitas antioksidan yang tinggi dengan nilai $\mathrm{IC}_{50}$ adalah $34,659 \mu \mathrm{g} / \mathrm{mL}$. Adanya perbedaan nilai $\mathrm{IC}_{50}$ pada masing-masing ekstrak dikarenakan adanya perbedaannya kandungan kimia yang terdapat pada masing-masing ekstrak tersebut. Sehingga mempengaruhi persen inhibis dan nilai $\mathrm{IC}_{50}$ yang diperoleh.

\section{KESIMPULAN}

Berdasarkan hasil penelitian yang telah dilakukan, maka dapat disumpulkan bahwa aktivitas antioksidan eksktrak daun daruju (Acanthus ilicifolius L.) pada ekstrak n-heksana aktivitas antioksidan tidak aktif dengan nilai IC $_{50} 361,730$ $\mu \mathrm{g} / \mathrm{ml}$, pada ekstrak etil asetat aktivitas antioksidan lemah dengan nilai $\mathrm{IC}_{50} 162,512 \mu \mathrm{g} / \mathrm{ml}$ dan pada 
ekstrak etanol memiliki aktivitas antioksidan yang kuat dengan nilai $\mathrm{IC}_{50} 34,659 \mu \mathrm{g} / \mathrm{ml}$. Sedangkan kuersetin sebagai pembanding memiliki nilai $\mathrm{IC}_{50}$ $11,955 \mu \mathrm{g} / \mathrm{ml}$.

\section{DAFTAR PUSTAKA}

Anonim 1986, 'Sediaan Galenik', Edisi 1, Departemen Kesehatan Republik Indonesia, Jakarta, p.10.

Avijit, D, Sarkar, R, Howlader, IS, Hamiduzzaman, \& Al-Hossain, 2012, 'Phytochemical Screening and The Evaluation of The Antioxidant, Cytotoxic And Antimicrobial Properties Of Acanthus ilicifolius (Family: Acanthaceae)', Vol.3, no. 8, pp. 153.

Djamil, R, Desfonda, L, 2010, 'Isolasi Dan Identifikasi Jenis Senyawa Flavonoid dalam Fase n-Butanol dari Ekstrak Metanol Daun Daruju (Acanthus ilicifolius Linn.), Acanthaceae.

Erviana, L, Malik, A \& Najib, A 2016, Uji Aktivitas Antiradikal Bebas Ekstrak Etanol Daun Kemangi (Ocimum basilicum L.) Dengan Menggunakan Metode DPPH, Jurnal Fitofarmaka Indonesia, vol 3, no. 2, pp.164168.

Firdaus, M, Prihanto, AA, Nurdiani, R, 2013, 'Antioxidant and cytotoxic activity of Acanthus ilicifolius flower', Vol,3, no.1, pp 17-21.

Gandjar, I,G \& Rohman, A 2007, Kimia Farmasi Analisis, Pustaka Pelajar, Yogyakarta, pp.261-262

Gayathri, G.A, Mahaligam, G, Nathiya, R, 2014, 'Quantitative Phytochemical Analysis, In vitro Reducing Power and Anti-oxidant Activity of Methanol Leaf Extract of Acanthus ilicifolius', Vol.7, no.1, pp. 181186

Govindasamy, C, Arulpriya, M,2013,'Antimicrobial activity of Acanthus ilicifolius: Skin infection pathogens', Vol.3, no.3, pp. 180183.

Gusdinar, T, Herowati, R, Kartasasmita, RE, \& Adnyana, IK 2009, Sintesis Kuersetin Terklorinasi dan Aktivitas Perlindungan terhadap Tukak Lambung, Majalah Farmasi Indonesia, 20(4), pp. 171-177.

Hamid, AA, Aiyelaagbae, OO, Usman, LA, Ameen, OM, \& Lawal, A, 2010, 'Antioxidants: Its medicinal and pharmacological Applications', Vol. 4, no.8, pp 142-151.

Hanani, Endang, 2015, Analisis Fitokimia, Buku Kedokteran EGC, Jakarta, p.10.

Harborne, J, B. 1987, Metode Fitokimia: Penuntun Cara Modern Menganalisa Tumbuhan
Terbitan Kedua, Terjemahan Kosasih Padmawinata dan Iwang Soediro, ITB, Bandung.

Harmita., 2006, Petunjuk pelaksanaan Validasi Metode dan Cara Perhitungannya. FMIPA, Universitas Indonesia: Depok

Irianti, T, Puspitasari, A, Suryani, E,' Aktivitas Penangkapan Radikal 2,2-Difenil-1Pikrilhidrazil oleh Ekstrak Etanolik Batang Brotowali (Tinospora crispa (L.) Miers) dan Fraksi-Fraksinya, The Activity of Radical Scavenging 2,2-Difenil-1-Pikrilhidrazil by Ethanolic Extracts of (Tinospora crispa (L.) Miers) Stem and Its Fractions, Vol.16, no.3, pp.139-146.

Julfitriyani, Runtuwene, RM, Wewengkang, D, 2016, 'Uji Aktivitas Antioksidan Dan Toksisitas Ekstrak Etanol Daun Foki Sabarati (Solanum Torvum), Vol.5, no.3.

Kosasih, EN, Setiabudhi, T, Heryanto, H 2004, Peranan Antioksidan pada Lanjut Usia, Pusat Kajian Nasional Masalah Lanjut Usia, Jakarta, hal. 56-57.

Kumalaningsih, S 2006, Antioksidan Alami, Penangkal Radikal Bebas: Sumber, Manfaat, Cara Penyediaan Dan Pengolahan, Cetakan Pertama, Trubus Agrisarana, Surabaya, hal. 24.

Liu, Lin, Fan, Hui, Qi, Ping, Mei, Yan, Zhou, Lijuan, Liping, Cai, Xing, Lin \& Lin, Jun 2013,'Synthesis and hepatoprotective properties of Acanthus ilicifolius alkaloid A and its derivatives', Exprimental and therapeutic medicine, Vol. 6, pp. 796-802.

Marliana, SD, Suryanti, Venty \& Suyono, 2005, Skrining Fitokimia dan Analisis Kromatografi Lapis Tipis Komponen Kimia Buah Labu Siam (Sechium edule jacq. Swartz) Dalam Ekstrak Etanol, Universitas Sebelas Maret, Surakarta

Miksusanti, Elfita, Hotdelina, S, 2012, 'Aktivitas Antioksidan dan Sifat Kestabilan Warna Campuran Ekstrak Etil Asetat Kulit Buah Manggis (Garcinia mangostana L.) dan Kayu Secang (Caesalpinia sappan L.)', Vol. 15 , no.2.

Molyneux, P., 2004, The Use Of The Stable Free Radical DiphenylPicrylhydrazyl (DPPH) For Estimating Antioxidant Activity, Songklanakarin J. Sci. Technol, vol 26, no.2, pp.211-219.

Munawar, Lungguh, 2016, Pengaruh Konsentrasi Senyawa Phospat Dan Perbandingan Air Perebusan Terhadap Karakteristik Tepung Instan 
Hanjeli (Coix Lacryma-Jobi L.), Universitas Pasundan Bandung

Najib, A., Hartati, S. and Elya, B. (2011) 'In vitro bioassay of n-buthanol isolate of Acorus calamus L. on inhibitory of activity aglucosidase', International Journal of PharmTech Research, 3(4), pp. 2085-2088.

Nugraha, R, Batubara, R, Ginting, H,' Uji Aktivitas Antioksidan Ekstrak Etanol Daun Gaharu (Aquilaria malaccensis Lamk) Berdasarkan Umur Pohon, Activity Testing of Ethanol Extract Antioxidant of Agarwood Leafs (Aquilaria malaccensis Lamk) Based on The Age Of The Tree', 2015, Vol. 4, no.1

Noor, Y., R. Khazali, M. Suryadiputra, I. N. N. 1999, 'Panduan Pengenalan Mangrove di Indonesia', Wetlands InternationalIndonesia Programme, Bogor.

Sachin, R, Shahana, K, Rupali, G, 2014, 'Isolation and characterization of major phytoconstituents from the leaves of Rhizophora mucronata Lamk and Acanthus ilicifolius Linn. ', Vol. 2, no.2, pp. 51-59.

Saranya, A, Ramanathan, T, Kesavanarayanan, SK, \& Adam, A 2015, 'Traditional Medical Uses, Chemical Constituents and Biological Activities of a Mangrove Plant, Acanthus ilicifolius Linn.: A Brief Review', Vol. 15, no. 2, pp. 243-250.

Silalahi, J 2006, Makanan Fungsional, Penerbit Kanisius, Yogyakarta, p.40.

Simanjuntak, K, 2012, 'Peran Antioksidan Flavonoid Dalam Meningkatkan Kesehatan', Vol. 23, no. 3, pp 135-140.

Sudjaji, 2007, Kimia Farmasi Analisis, Pustaka Pelajar, Yogyakarta.

Suparmi, Anshory, H, Dirmawati, N, 2012,' Uji Aktivitas Etanol Kulit Buah Rambutan (Nephelium lappaceum, L.) dengan metode Linoleat-Tiosianat', Vol.9, no.1

Syamsuni, A, D, H 2006, Ilmu Resep, Peneribit Buku Kedokteran, EGC, Jakarta, p.243.

Syarif, RA, Muhajir, M, Ahmad, AR \& Malik, A 2015, Identifikasi Golongan Senyawa Antioksidan Dengan Menggunakan Metode Peredaman Radikal DPPH Ekstrak Etanol Daun Cordia myxa L., Jurnal Fitofarmaka Indonesia, vol 2, no. 1, pp. 83-89.

Tarigan, D., 2009, Penentuan Kadar Natrium Sklamat Minuman Ringan Secara Spektrofotometri Uv-Vis, Skripsi, Universitas Sumatera Utara, Medan.

Utomo, AR, Retnowati, R., Juswono, UP 2013, 'Pengaruh Konsentrasi Minyak Kenanga (Cananga odorata) Terhadap Aktivitasnya
Sebagai Antiradikal Bebas', Kimia Student Journal, Vol 1 (02), pp. 265

Waris, R, Najib, A \& Pratiwi, ED 2016, Radical Scavenging Activity of Leaf Extract of Edible Hibiscus (Abelmoschus Manihot (L.) Medik) Using 1,1- Diphenyl-2-Picryl Hydrazil (DPPH), International Journal of PharmTech Research, vol 9, no. 6, pp. 343347.

Widyowati, H, Ulfah, M, Sumantri, 2014, 'Uji Aktivitas Antioksidan Ekstrak Etanolik Herba Alfalfa (Medicago sativa L.) Dengan Metode DPPH (1,1-diphenil-2pikrylhidrazil)', Vol.11, no. 1

Winarsih H, 2007, Antioksidan Alami dan Radikal Bebas; Potensi dan Aplikasinya dalam Kesehatan, Kanisius, Yogyakarta.

Wostmann, R, Liebezeit, G, 2008,' Chemical Composition of the Mangrove Holly Acanthus ilicifolius (Acanthaceae) - Review and Additional Data'. Senckenbergiana Maritima, vol 38 no. 1 hal. 31-3

Yenrina, R, \& Sayuti, K 2015, Antioksidan, Alami dan Sintetik, Andalas University Press, Padang, pp 75-76.

Yuliani, S, Satuhu, S., 2012. Panduan lengkap minyak atsiri. Penebar swadaya: Jakarta. 